\title{
Violence Against Authority: Management, Policy, And Research Implications
}

\author{
Randy R. Edwards, Simpson College, USA \\ C. Kenneth Meyer, Drake University, USA \\ Stephen E. Clapham, Drake University, USA
}

\begin{abstract}
There has been a steady decline in violent crime in the United States in the past twenty years. Trends indicate that violent crime was down 13.4 percent below the $200 \mathrm{l}$ level and for property crime, society is experiencing the tenth straight year of declining rates. Yet, the Southern region of the U.S is disproportionately represented by percentage of overall violent crimes committed nationally. Also, the South is over-represented in the number of police officers who are feloniously killed or assaulted. This empirical research concentrates on violence directed against police in the U.S. and begins by examining the type and magnitude of workplace violence, then transitions to a review of the sociological, political, and psychological literature, focusing on the individual and social causes for violence generally. It ends with an examination of officers feloniously killed (their personal characteristics and that of their assailants), the level of violence against police by type of arrest or enforcement situation, and by region of the country.
\end{abstract}

This paper provides a comparative analysis of street-level violence for general municipal assaults, robbery, and the most rapidly growing type of felonious assault-ambush attacks. The paper concludes with an analysis of the societal and behavioral characteristics and considerations related to violence against police. The authors present a number of current trends, training recommendations, and suggestions for improving officer workplace safety.

Keywords: Violent Crime Rate; Workplace Violence; Police Line-Of-Duty Deaths; Violence Against Police; Felonious Assault; Ambush

\section{INTRODUCTION}

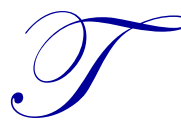
here has been a slow yet steady decline in violent crime in the United States in the past twenty years. According to the FBI's Uniform Crime Reporting (UCR) Program, violent crime is composed of four offenses; murder and non-negligent manslaughter, forcible rape, robbery and aggravated assault. Overall, there has been a reduction in virtually all types of violent crime, in all four regions of the U.S.

In 2010, aggravated assaults accounted for the highest number of reported violent crimes at 62.5 percent. Robbery was reported at 29.5 percent, forcible rape at 6.8 percent and murder accounted for 1.2 percent of violent crimes reported. Violent crime was down 6.0 percent in 2010 from 2009. Trends indicate that violent crime is 13.2 percent below the level in 2006, and 13.4 percent below the 2001 level. For a crime weary populace this represented a positive trend.

This trend was reversed as illustrated in recent figures from the FBI's crime in the United States 2012, Uniform Crime Reports. Overall, law enforcement agencies throughout the nation reported a slight increase of 0.7 percent in the number of violent crimes committed in $2012-1,214,462$ crimes reported. The violent crime arrest rate for murder and non-negligent manslaughter for 2012 was 3.5; forcible rape, 5.8; robbery, 33.1; and the aggravated assault, 123.9 per 100,000 inhabitants. However, the number of property crimes in the U.S. actually decreased 0.9 percent - the tenth straight year of decline in property crime rates - to 8,975,438 crimes reported. Correspondingly, the property crime arrest rate for burglary was 90.7 ; larceny-theft, 411.9, and motor vehicle theft, 21.9. The arrest 
rate for arson was 3.7 per 100,000 inhabitants, 2012. The US violent crime statistics by volume and rate for 1991 to 2012 are reported in Table 1. This data is also reflected for violent crime figures for the 2006 to 2012 period in Figure 1.

Table 1: Crime In The United States By Volume And Rate Per 100,000 Inhabitants (1991-2012)

\begin{tabular}{|c|c|c|c|}
\hline Year & Population $^{1}$ & Violent Crime & Violent Crime Rate \\
\hline 1991 & $252,153,092$ & $1,911,767$ & 758.2 \\
\hline 1992 & $255,029,699$ & $1,932,274$ & 757.7 \\
\hline 1993 & $257,782,608$ & $1,926,017$ & 747.1 \\
\hline 1994 & $260,327,021$ & $1,857,670$ & 713.6 \\
\hline 1995 & $262,803,276$ & $1,798,792$ & 684.5 \\
\hline 1996 & $265,228,572$ & $1,688,540$ & 636.6 \\
\hline 1997 & $267,783,607$ & $1,636,096$ & 611.0 \\
\hline 1998 & $270,248,003$ & $1,533,887$ & 567.6 \\
\hline 1999 & $272,690,813$ & $1,426,044$ & 523.0 \\
\hline 2000 & $281,421,906$ & $1,425,486$ & 506.5 \\
\hline $2001^{2}$ & $285,317,559$ & $1,439,480$ & 504.5 \\
\hline 2002 & $287,973,924$ & $1,423,677$ & 494.4 \\
\hline 2003 & $290,788,976$ & $1,383,676$ & 475.8 \\
\hline 2004 & $293,656,842$ & $1,360,088$ & 463.2 \\
\hline 2005 & $296,507,061$ & $1,390,745$ & 469.0 \\
\hline $2006^{3}$ & $299,398,484$ & $1,435,123$ & 479.3 \\
\hline $2007^{3}$ & $301,621,157$ & $1,422,970$ & 471.8 \\
\hline $2008^{3}$ & $304,059,724$ & $1,394,461$ & 458.6 \\
\hline $2009^{3}$ & $307,006,550$ & $1,325,896$ & 431.9 \\
\hline 2010 & $308,745,538$ & $1,246,248$ & 403.6 \\
\hline 2011 & $311,587,816$ & $1,206,031$ & 387.1 \\
\hline 2012 & $313,014,040$ & $1,214,464$ & 366.9 \\
\hline
\end{tabular}

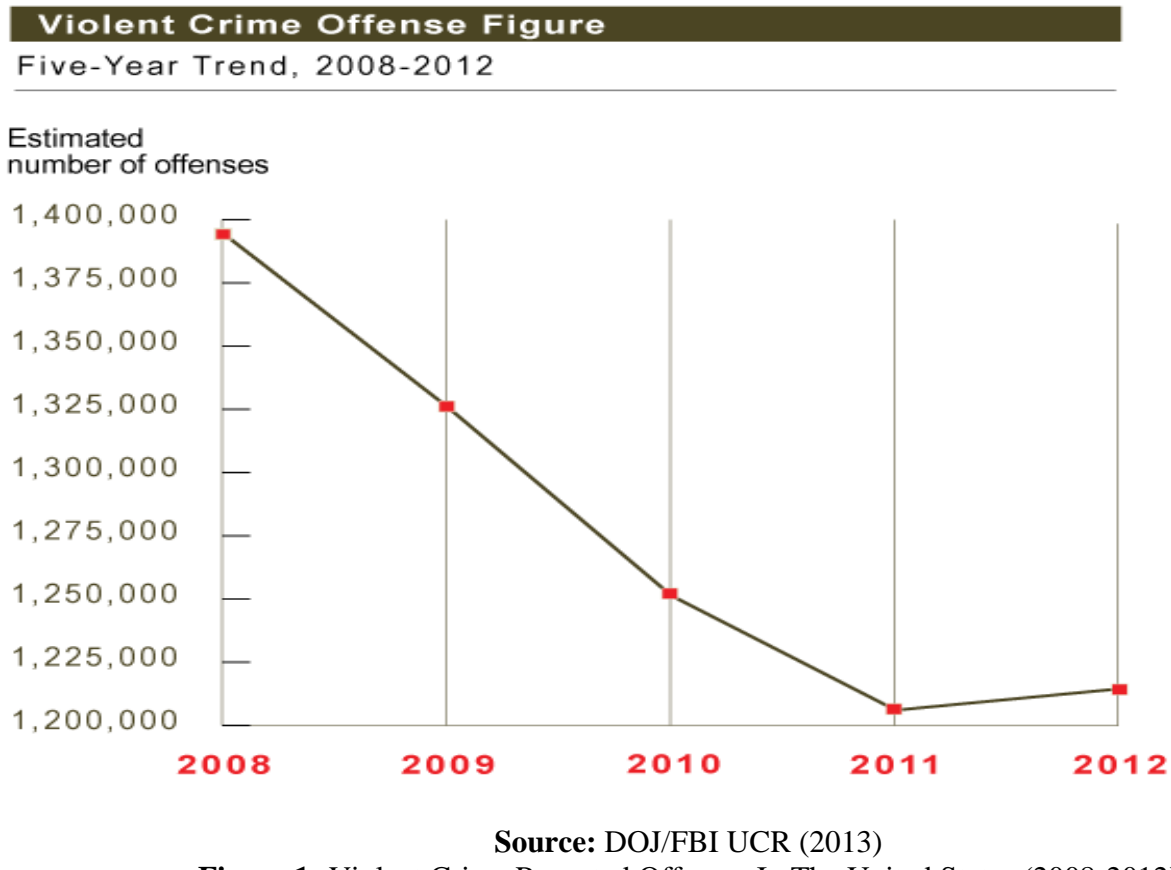

Figure 1: Violent Crime Reported Offenses In The United States (2008-2012) 
When regional geographical divisions are considered for the 2012 period the Southern region is disproportionately represented by percentage overall violent crimes committed nationally. In the South 40.1 percent of all violent crimes were reported in contrast to 16.0 percent, the lowest of all regions, for the Northeast. Marginally, these statistics have remained stable during the past few years, despite a slight growth in population size in the South and Western census regions, and a decrease in the percent of the population residing in the Midwest and the Northeast as shown in Table 2.

Table 2: Violent Crime And Population Percentages By Region (2012)

\begin{tabular}{|c|c|c|}
\hline Region & Population $^{\mathrm{a}}$ & Violent Crime \\
\hline 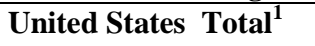 & 100.0 & 100.0 \\
\hline Northeast & 17.8 & 16.0 \\
\hline Midwest & 21.4 & 19.7 \\
\hline South & 37.3 & 40.1 \\
\hline West & 23.4 & 23.4 \\
\hline
\end{tabular}

${ }^{a}$ Because of rounding, the percentages may not add to 100.0 .

Source: UCR (2012) Table 4

The US Bureau of the Census created four regions of the United States for statistical analysis. Each region includes states (as listed below) and is geographically displayed in Figure 2.

Northeast Region: CT, ME, MA, NH, N J, NY, PA, RI, VT

Midwest Region: IA, IL, IN, KS, MI, MN, MO, NE, OH, ND, SD, WI

South Region: AL, AR, DE, FL, GA, KY, LA, MD, MS, NC, OK, SC, TN, TX, VA, WV

West Region: AK, AZ, CA, CO, HI, ID, MT, NV, NM, OR, UT, WA, WY

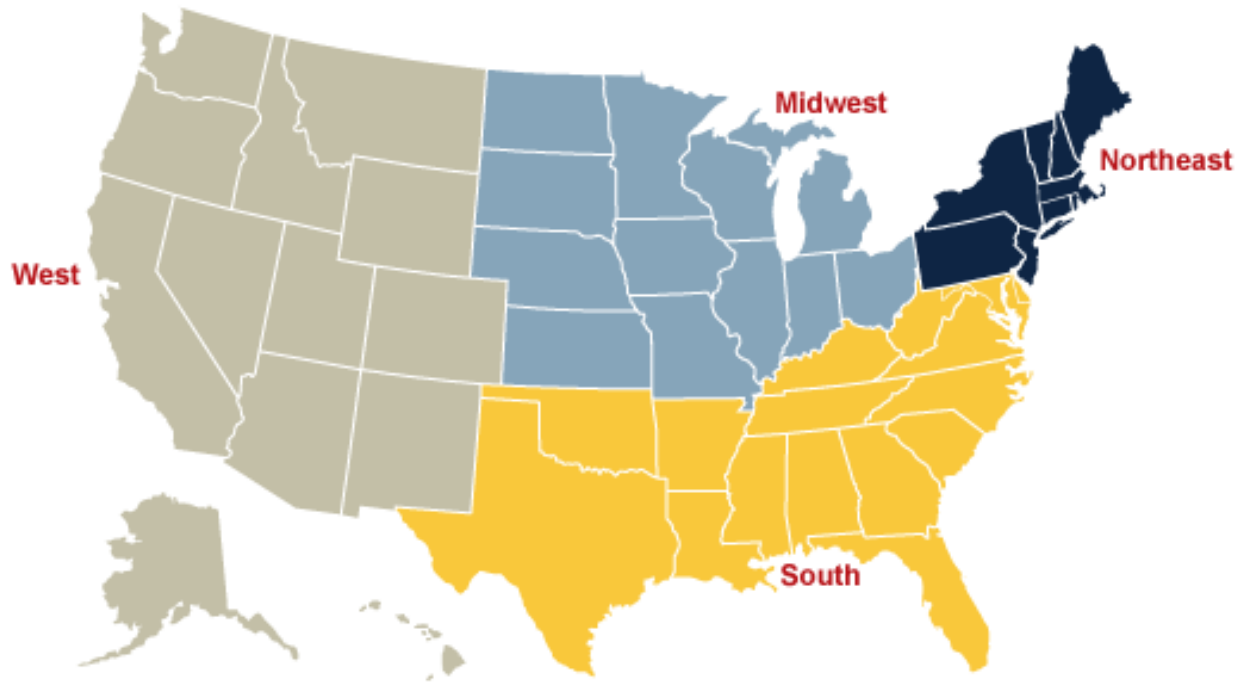

Figure 2: Census Regions Of The United States

These crime statistics become important when this study examines the number and type of felonious assaults on law enforcement officers nationally. This study will show the percent of officers feloniously killed by circumstance for the time period 1980 to 2012. In addition, data will be shown for the number and percent of all officers assaulted by geographical region for the 14 year period, 1996 to 2010. As revealed in Table 3, the South, proportionate to its population size, has a much higher percentage of law enforcement officers feloniously killed and officers assaulted than would be expected. As the data shows for 2003 to 2012 the South reported 48.8 percent of all officers killed. 
Table 3: Officers Feloniously Killed By Region (2003-2012)

\begin{tabular}{|c|c|c|}
\hline Region & Number Of Officers Killed & Percent \\
\hline Northeast & 59 & 11.5 \\
\hline Midwest & 94 & 18.3 \\
\hline South & 251 & 48.8 \\
\hline West & 110 & 21.4 \\
\hline Total & 514 & 100.0 \\
\hline
\end{tabular}

Source: Federal Bureau of Investigation, Law Enforcement Officers Killed and Assaulted, Washington, D.C.: U.S. Department of Justice, 2001; 34, 2002; 34, 2003; 52, 2004; 63, 2005; 63, 2006; 63; 2007; 65, 2008; 65, 2009; 65 and 2010; 65, 2011; 65, $2012: 1$.

The incident of police killings is wrapped in findings that are counter-intuitive. Overall, deaths by felonious attack dovetailed with increases in violent crime. So, as recently as 2007 , a fifteen percent spike in violent crime was associated with an increase in police deaths. This would normally be expected to take place given the general nature of violence as it shows itself in society. However, in 2010 and 2011, the decline in the rate of violent crime per 100,000 inhabitants was associated with an increase in the number of officers killed - 56 and 72 , respectively.

In a complimentary way statistically, the South as historically reported, has had the highest percentage of all violent crimes in the United States, year after year; and, likewise, the highest percentage of homicides and the highest percentage of officers assaulted or feloniously killed. The question remains unanswered as to what undergirds the Southern level of violence. Some analysis points the larger percent of the total population that lives in the South when compared to the other census regions, and, therefore, would have more officers employed, thus increasing the assault probability. For instance, for the 1995 to 2004 period, the South had 47 percent of all slain officers and the Northeast had only 9 percent of felonious officer deaths.

The LEOKA for 1995-2004 periods addressed the geographical preponderance of homicides, fatally attacks on police and police assaults. When the assault rate is calculated per 100 officers, the South once more stood out with a rate of 14 per 100 officers, contrasted with 11 assaults per officer in the Midwest and Western census regions and 10 in the Northeast. This phenomenon remained unexplained. However, it should be asked if there are unique societal features that drive these violent levels in the South that are distinctly different from the other regions? Or, does the training protocol for police and style of enforcement partially explain this dramatic variability in police deaths and assaults. LEOKA reported that for the 1981-1990 period the South employed 33 percent of the Nation's total police, the Midwest employed 23 percent, the Northeast employed 25 percent and the West 19 percent of total number of officers. When employment figures are factored into the statistics, the South once more had a disproportionate level of police fatalities in contrast with the other regions.

The substance of this paper is not directed at identifying the multiple reported causes of crime, for they are hypothesized to be associated with factors as different as TV violence to poor parenting to poverty, deprivation, and even ecological reasons associated with temperature and weather. For this study the authors are utilizing the ten factors listed as the causes of crime by the FBI in their Uniform Crime Report.

1. Population density and degree of urbanization.

2. Variations in composition of the population, particularly youth concentration.

3. Stability of population with respect to resident's mobility, commuting patterns and transient factors.

4. Modes of transportation and highway systems.

5. Economic conditions, including medium income, poverty level and job availability.

6. Cultural factors and educational, recreational and religious characteristics.

7. Family conditions with respect to divorce and family cohesiveness.

8. Climate.

9. Effective strength of law enforcement agencies.

10. Administrative and investigative emphases of law enforcement. 


\section{WORKPLACE VIOLENCE IN THE UNITED STATES}

According to the National Law Enforcement Officers Memorial Fund, on average, one law enforcement officer is killed in the line of duty (feloniously killed or accidentally killed) in the U.S. every 53 hours or an average of 163 per year. Yet despite this yearly death toll, police do not rank in the top ten of deaths related to occupational status. Fishermen, loggers, taxicab drivers, airplane pilots and flight engineers, and retail store operators have a higher on-the-job death rate than police. Statistically, the occupations with the highest injury rates per 100,000 full-timeequivalent (FTE) workers were for loggers (129.9), fishers (120.8), aircraft pilot and flight engineers (54.3), roofers (42.2) and farmers/ranchers (22.8). The national fatal injury rate for 2012 was 3.4 per 100,000 FTEs. The total number of work fatalities dropped from 6,217 in 1992, to 4,628 in 2012 - a decrease of 26 percent (www.bls.gov/iif/oshwc/cfoi/cfchco11.pdf). The magnitude of workplace violence is also statistically assessed by the Bureau of Labor Statistics' (BLS) Census of Fatal Occupational Injuries (CFOI). The BLS reported that 13,827 workplace homicides were committed during the 1992-2010 timeframe, averaging over 700 homicides per year. In 1994, 1,080 people were the victims of homicides in the workplace and 518 took place in 2010 - the lowest number in the reported eighteen-year period (http://www.cdc.cdc.gov/niosh/topics/violence/).

In contrast, during the 2003-2010 period, approximately 137,000 nonfatal assaults against workers occurred that required treatment in emergency departments. Further, National Crime Victimization Survey (NCVS), conducted by the Bureau of Justice Statistics (BJS) reported the number of nonfatal violence crimes against victims 16 or older at work in 2009 at 572,000. These numbers, of course, are daunting in their size, especially since the Occupational Safety and Health Act General Duty Clause requires employers to provide a safe and healthful workplace for all workers covered by the OSH Act (https://www.osha.gov/Publications/osha3021.pdf). OSHSA, 1970, requires States to set job safety and health standards that are at least as effective as comparable federal standards and 22 of the states have their own plans that are in compliance with federal requirements and cover both private and state and local government employees (www.OSHA.gov/law-regs.html) In 2011, the BLS ranks homicide as the fourth leading cause of workplace deaths $(\mathrm{n}=468)$. Robbers were the assailants in 34 percent of the workplace killings and 10 percent were co-workers or work associates of victims. Another 10 percent were customers or clients of the victims (http://www.bls.gov/iif/osh nwrl.htm\#cfoi). Last, in 2012, 767 workers were killed on the job. Firearms or shootings were involved in 463 of the homicides, or 81 percent, and firearms were used in 48 percent of the suicides that took place at work (http://www.bls.gov/iif/osh nwrl.htm\#cfoi). In 2011, 47.8 per cent of government workers were shot and killed by a coworker while on the job (www.bls.gov/opub/btn/volume-2/death-on-the-job). However, the catchy phrase of "going postal" is not an accurate depiction when the rate is calculated using the total number of government workers in the United States or in the United States Postal Service.

Data from the Center of Disease Control and Prevention (CDCP) demonstrate that nearly 60 percent of all homicides that took place in the workplace between 2003-2010, were associated with only three occupational groupings: 29 percent took place in sales and related occupations, 17 percent in protective service occupations, and transportation and material moving occupations accounted for 13 percent of all reported workplace related deaths (Occupational Violence, 2014: http://www.cdc.gov/niosh/topics/violence/).

These numbers are consistent with the conclusions of the U.S. Occupational Safety and Health Administration (OSHA) analysis of risk factors associated with being a victim of workplace violence. They list the following high risk occupational characteristics for workplace violence: workers who exchange money with the public; delivery drivers; healthcare professionals; public service workers; customer service agents; law enforcement personnel; and people who work alone or in small groups (Workplace Violence, 2014: https://www.osha.gov/SLTC/workplaceviolence/). In nearly all of these circumstances, those who work in occupations that have these attributes are at higher risk than those who do not have regular contact and interaction with the public, which is certainly the case with associates who work in convenience stores, drive taxis, who are likely to work alone or in small groups. Obviously, law enforcement personnel are in the business of enforcing societal laws and regulations, such as responding to a burglary or robbery in progress, to a suspicious person, family disturbance, or to making routine traffic stops share some of these high-risk attributes. Additionally, law enforcement officers are further faced with the uncertainty of making arrests on those who they encounter in performing the sundry and routine patrol duties. 
Concurrently, the data compiled by OSHA give added support to the CDCPs' statistics since these areas were also described as high-risk occupations for workplace violence. In addition, The Bureau of labor Statistics (BLS) reported that in their analysis of workplace homicides due to shootings in 2010, by industry, that of the 405 reported incidents, 27 percent occurred in retail trade; followed by 17 percent in government; 15 percent in leisure and hospitality, and then 8 percent, respectively, in other services, except public administration and transportation and warehousing. As Figure 3 shows, the other sectors accounted for only 3 to 6 percent of the total shootings (Workplace Homicides from Shootings, 2013: https://www.osha.gov/SLTC/workplaceviolence/ ).

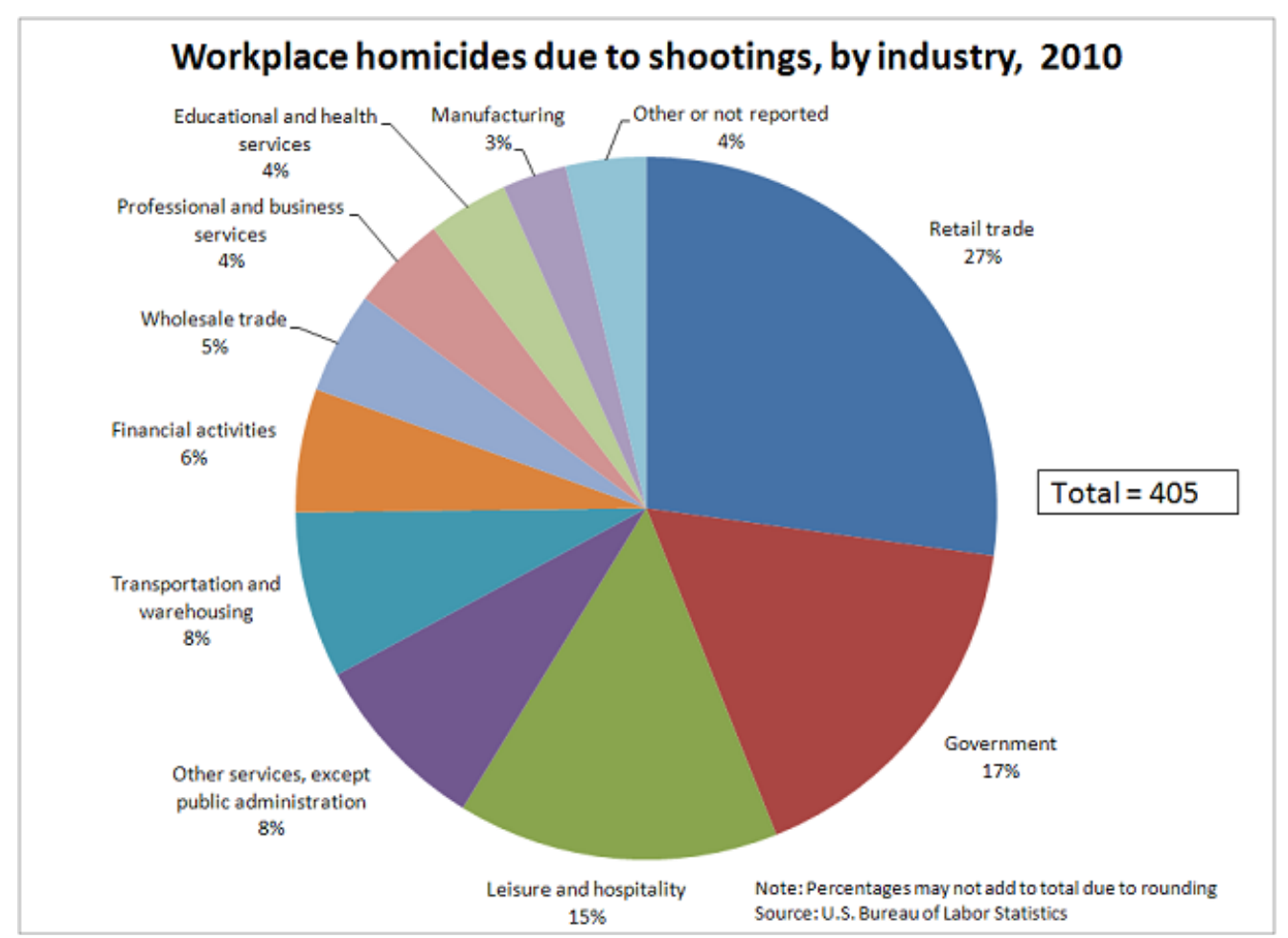

Figure 3: Workplace Homicides Due To Shootings By Industry (2010)

The FEMA Emergency Management Institute presents information for individuals and organizations interested in increasing workplace security regardless of the setting. They state that no entity is immune from safety threats, and assert "Employees are often the target of these threats as well as the organization's first line of defense against them" (IS-906: Workplace Security Awareness, 2013: www.usasearch.fema.gov/search?query= workplace+security+awarness\&op=Search\&affiliate=fema). Especially instructive is the admonition to employees that they need to develop a security awareness mindset that includes an awareness of such things as knowing the location of emergency equipment, knowledge of the building evacuation plan and, among other factors, ability to do an environmental scan and develop an awareness of behavior(s) that seems out of the ordinary or suspicious (unusual). The Institute also lists warning signs that should be included in one's tool chest of safety and security precautions concerning behaviors that are displayed in the workplace: Depression and/or withdrawal; repeated violations of organizational policies; explosive outbursts of anger or rage without provocation; behavior that might indicate paranoia; escalation of domestic problems into the workplace; talk of severe financial problems, and talk of previous incidents of violence. (IS-906: Workplace Security Awareness, 2013: http://training.fema.gov/is /courseoverview.aspx?code=IS-906). In summary, workers at all organizational levels need to know how to identify behavior that is suspect and know the proper manner for reporting it, as well as purposely developing an outlook toward preventing workplace violence that is anticipatory or proactive in nature.

Stephen Romano, et al. (2011) examined workplace violence and placed fatal and nonfatal incidents into a fourfold typology: Type I - Offender has no relationship with the victim or workplace establishment. In these incidents, the motive most often is robbery or another type of crime. Type II - Offender currently receives services 
from the workplace, often as a customer, client, patient, student, or other type of consumer. Type III - Offender is either a current or former employee who is acting out toward coworkers, managers, or supervisors. And type IV Offender is not employed at the workplace, but has a personal relationship with an employee. Often, these incidents are due to domestic disagreements between and employee and the offender (Romano, et al. 2011). Of these four types of violent acts, Type I is most representative of felonious deaths and of officers' assaulted during policecitizen encounters, followed by Type II, if a person who is being stopped or arrested is considered a client and/or customer.

This study now examines the magnitude and characteristics associated with deaths of law enforcement officers that resulted from felonious attacks and assaults of police in the United States. This paper does not attempt to re-examine and test the many theories that have been presented over the years in search for a better understanding of violent behavior in society. Nevertheless, some of these theories have been important in aiding the understanding of the individual and societal causes for violence. Many of the antiauthority theories are interesting and appeal to have at least some face validity, but researchers lack the empirical data now to test them for their veracity and their predictive ability. In the literature, violence is often thought to stem from factors as diverse as learned behavior (i.e., cultural conditioning - adopting values and customs, including the use of violence, engrained in cultures), psychological (i.e., from Freudian psychology to Maslow's Need Fulfillment), genetic (i.e., chromosome composition and eugenicists theories), and/or environmental factors. Others suggest that violence is a response to modern society (relative deprivation, Friedrich Engles, Lewis Mumford, and Robert Presthus), or to interest groups and their influence and behavior, leading to the legitimacy of government being questioned as both the structure of the government and the structure of the economy become simultaneously undermined. Still others see the decline in morality, especially during periods of class conflict to violence as goal-directed behavior. Still others posit the ecological models of violence reflected in socio-economic-psychological measurements of crime, violence and criminality. More recently violence may even be thought of as a contagious disease that, in turn, enables us to study it as an epidemiological phenomenon (Meyer et. al. 2001).

\section{Officers Feloniously Killed}

Since the 1960's, the level of antipolice violence has stabilized at a high level. Recognizing this shift has another implication. While it appears that the action, of some individual officers might be the trigger for certain violent responses by their assailants, the fundamental sources of American antipolice violence must lie at a much deeper level than the individual officer. Violence has become a constant hazard of police work. Increase the number of police officers within reasonable bounds and the number of attacks on the police goes up proportionately. Decrease the number of officers, and the amount of antipolice violence declines, as well (Meyer, et. al, 2001).

An important factor for consideration is the actual number of officers employed in any given year. This number is determined by current department, state and federal budgets and is in a current state of flux throughout the country, especially during the economic recession, 2008 to 2011. According to the Department of Justice, 64 percent of police departments around the country were forced to cut budgets during 2011, and as reported by CNN, this action has taken nearly 15,000 police officers off the streets (Caulfield, 2011).

Society has come to believe that increases in killings and assaults of law enforcement officers have historically corresponded with increases in violent crime. This has been true to a degree. However, the numbers of law enforcement officers killed in the line of duty, as shown in Table 4, has remained reasonably stable for the period 2000 to 2012 ranging from a low of 41 officers killed in 2008 to a high of 72 killed in 2011, and a mean average of 54.7 for the same time period.

Contrary to popular belief, the number of officers feloniously killed is actually declining. For instance, the 1970s were the deadliest decade in law enforcement history, when a total of 2,286 officers died, or an average of almost 229 each year (feloniously and accidentally killed). That figure dropped dramatically in the 1990s, to an average of 160 per year. 
Table 4: Law Enforcement Officers Killed In The Line-Of-Duty (1980-2012)

\begin{tabular}{|c|c|c|c|}
\hline Year & Officers Feloniously Killed & Officers Accidentally Killed & Total \\
\hline 1980 & 104 & 61 & 165 \\
\hline 1981 & 91 & 66 & 157 \\
\hline 1982 & 92 & 72 & 164 \\
\hline 1983 & 80 & 72 & 152 \\
\hline 1984 & 72 & 75 & 147 \\
\hline 1985 & 78 & 70 & 148 \\
\hline 1986 & 66 & 67 & 133 \\
\hline 1987 & 74 & 74 & 148 \\
\hline 1988 & 78 & 77 & 155 \\
\hline 1989 & 66 & 79 & 145 \\
\hline 1990 & 66 & 67 & 133 \\
\hline 1991 & 71 & 53 & 124 \\
\hline 1992 & 64 & 66 & 130 \\
\hline 1993 & 70 & 59 & 129 \\
\hline 1994 & 79 & 62 & 141 \\
\hline 1995 & 74 & 59 & 133 \\
\hline 1996 & 61 & 51 & 112 \\
\hline 1997 & 70 & 63 & 133 \\
\hline 1998 & 61 & 81 & 142 \\
\hline 1999 & 42 & 65 & 107 \\
\hline 2000 & 51 & 84 & 135 \\
\hline 2001 & 70 & 76 & 146 \\
\hline 2002 & 56 & 75 & 131 \\
\hline 2003 & 52 & 81 & 133 \\
\hline 2004 & 57 & 82 & 139 \\
\hline 2005 & 55 & 67 & 122 \\
\hline 2006 & 48 & 66 & 114 \\
\hline 2007 & 58 & 83 & 141 \\
\hline 2008 & 41 & 68 & 109 \\
\hline 2009 & 48 & 48 & 96 \\
\hline 2010 & 56 & 72 & 128 \\
\hline 2011 & 72 & 53 & 125 \\
\hline 2012 & 48 & 47 & 95 \\
\hline
\end{tabular}

Source: Federal Bureau of Investigation, Law Enforcement Officers Killed and Assaulted,_Washington, D.C.: U.S. Department of Justice, 1989:12, 1999:18, 2009:19, and 2012:

In terms of fatal attacks, as shown in Table 4, the decade of the 1980s, there were a total of 801 law enforcement officers feloniously killed in the U.S. During the decade of the 1990's, 658 officers were killed representing a decrease of 18 percent. And in the years 2000-2009, there were a total of 536 law enforcement officers feloniously killed in the line of duty - a decrease of 33 percent from the 1980's and a decrease of 19 percent from the 1990's.

\section{Felonious Attacks And Incident Circumstances}

For the first time in 20 years, more police officers were killed by gunfire than by on-duty automobile crashes. Firearms related fatalities for officers increased 70 percent from 2008 to 2011. In one 24-hour period (January 23, 2011), eleven officers were shot in five states, resulting in the deaths of three of the officers. Over the years, the circumstances in which officers are killed have remained fairly constant, as shown in Table 5. However, in the past decade, there has been a significant increase in the numbers of officers killed in ambush situations, 9 percent of officers feloniously killed in ambushes in the 1980 to 1989 period in contrast to 22 percent killed in the 2000 to 2009 period, and an increase in "cluster killings." Furthermore, it appears that a slow but steady increase of officer fatalities is occurring during aggressive forced-entry raids (which are also becoming more frequent - and more deadly). 
Table 5: Percent Of Officers Feloniously Killed By Circumstance At Scene Of Incident

\begin{tabular}{lccc}
\hline \multicolumn{1}{c}{ Circumstance } & $\mathbf{1 9 8 0 - 1 9 8 9}^{\mathbf{a}}$ & $\mathbf{1 9 9 0 - 1 9 9 9}^{\mathbf{b}}$ & $\mathbf{2 0 0 0 - 2 0 0 9}^{\mathbf{c}}$ \\
\hline Ambush Situation & 9 & 13 & 22 \\
Traffic Stop & 13 & 14 & 18 \\
Other & 6 & 5 & 12 \\
Arrest Situation & 41 & 35 & 23 \\
Disturbance Call & 17 & 16 & 14 \\
Investigating Suspicious Person or Circumstance & 14 & 17 & 11 \\
$\quad$ Total & $\mathbf{1 0 0}$ & $\mathbf{1 0 0}$ & $\mathbf{1 0 0}$ \\
\hline
\end{tabular}

Source: USDOJ, FBI: LEOKA ${ }^{\mathrm{a}}$ Table $12,{ }^{\mathrm{b}}$ Table $18,{ }^{\mathrm{c}}$ Table 19

\section{Ambush Attacks Against Police Officers}

An ambush incident is defined as either an entrapment situation where an officer is lured into an ambush with premeditation, or the officer is the victim of an unprovoked attack. Between 1980 and 1989 there were 70 officers killed in ambushes. Between 1990 and 1999, 87 officers were similarly killed. From 2003 to 2012, there were 115 officers feloniously killed in ambush situations.

In the decade of the 1980's, ambushes accounted for approximately 9 percent of fatal assaults on officers. In the decade of the 1990's, the number of ambush assaults resulting in officer deaths increased to 13 percent. In the past decade (2000-2009), ambushes were the cause of 22 percent of officer felonious deaths. Clearly, the numbers of officers being ambushed are steadily increasing. In both 2009 and 2010, more officers were killed in ambush situations than any other type of circumstance. In 2010, 15 officers were fatally ambushed; making it the leading cause of officer deaths, comprising 26.8 percent of all officers feloniously killed that year. Overall, ambushes are up 41.7 percent from the 1980 's. This fact has certainly caught the attention of the law enforcement community, because an ambush attack creates real challenges for law enforcement, particularly when it comes to developing effective countermeasures. Countermeasures for ambush attacks and other attacks on police require disaggregated data on the overall assaults. In only one other study on violence against police, have researchers been able to identify the triggering mechanisms that were at play at the time of a police assault.

One of the most comprehensive studies conducted on assaults against police to date, was reported in $\underline{A}$ Comparative Assessment of Police Assaults, in which the authors had direct evidence of the last word (s) or action(s) by either the police or the suspect in almost 1,300 municipal assault, 143 robbery, and 62 ambush incidents. Since this data was made available on a disaggregated basis, the authors were able to develop a six fold typology in which they were able to classify the officer's last words or actions by these major categories: threat to ego of suspect, nonphysical threat; physical action, physical restraint of suspect; neutral, passive behavior; performance of routine duties; defensive act; and other category. Employing roughly the same typology, they were able to use the six categories listed above, with a slight variation tailored to the behavior of the suspects, such as committing a general illegal action and defensive action and/or escape.

One possible motive suggested for a police assault is that personal hostilities between the officer and assailant may be a precursor that leads the assailant to attack the officer in retaliation for real or imagined grievances. As reported by the Police Assaults Study, in general and ambush-related assaults, a sizable percentage of assailants were known personally by the officer prior to the assault event: 21.0 percent in general assaults and 36.8 percent in Ambush attacks. However, in robbery-related assaults, over 95 percent of the actors involved in the assault situation were not acquainted with each other, and the assault could have grown out of the robbery situation itself and the assailant's desire to escape (Meyer et al., 1981; Meyer et al., 1982, Meyer et al., 1986).

The dynamics of the assault incident gets slightly clearer, when an analysis of officer and assailant activities, actions, and words prior to the assault events are tabulated. As shown in Table 6, using the typology presented above, the last words and acts prior to assault incident taking place are shown. 
Table 6: Officer's And Assailant's Last Words Or Actions Prior To Assault Categorized

\begin{tabular}{|c|c|c|c|c|c|c|}
\hline \multirow[t]{2}{*}{ Officer's Last Word, Action } & \multicolumn{2}{|c|}{ General } & \multicolumn{2}{|c|}{ Robbery } & \multicolumn{2}{|c|}{ Ambush } \\
\hline & $\mathbf{N}$ & $\%$ & $\mathbf{N}$ & $\%$ & $\mathbf{N}$ & $\%$ \\
\hline Threat to ego of suspect, nonphysical threat & 492 & 43.4 & 42 & 29.4 & 5 & 8.1 \\
\hline Physical action, physical restraint of suspect & 338 & 29.8 & 46 & 32.2 & 3 & 4.8 \\
\hline Neutral, passive & 91 & 8.0 & 30 & 21.1 & 21 & 33.9 \\
\hline Routine duties & 139 & 17.3 & 20 & 14.0 & 33 & 53.2 \\
\hline Defensive act & -- & -- & 4 & 2.8 & -- & -- \\
\hline Other & 74 & 6.5 & 1 & 0.7 & -- & -- \\
\hline Total & 1134 & 100.00 & 143 & 100.1 & 62 & 100.0 \\
\hline \multirow[t]{2}{*}{ Suspect's Last Word, Action } & \multicolumn{2}{|c|}{ General } & \multicolumn{2}{|c|}{ Robbery } & \multicolumn{2}{|c|}{ Ambush } \\
\hline & $\mathbf{N}$ & $\%$ & $\mathbf{N}$ & $\%$ & $\mathbf{N}$ & $\%$ \\
\hline Threat to ego of officer, nonphysical threat & 560 & 49.7 & 42 & 29.4 & 3 & 5.3 \\
\hline Physical action against officer & 327 & 29.0 & 70 & 49.0 & 39 & 68.4 \\
\hline Neutral, passive & -- & -- & 2 & 1.4 & 2 & 3.5 \\
\hline General illegal act & 71 & 6.3 & 9 & 6.3 & 8 & 14.0 \\
\hline Defensive act, escape & 106 & -- & 19 & 13.3 & 1 & 1.7 \\
\hline Other & 63 & 5.6 & 1 & 0.7 & 4 & 7.0 \\
\hline Total & 1127 & 100.0 & 143 & 100.1 & 62 & 99.0 \\
\hline
\end{tabular}

Source: Meyer, et al., 1981

These data represent the officer's reported version of what actually transpired and are revealed as: nonphysical or ego threats; physical actions against the other participant; neutral or passive suspect/officer behavior; routine duties or general illegal behavior; and defensive acts. In the analysis, Meyer, et al., 1986, report the following: “...TT]he differences between general, robbery-related, and ambush police assaults in terms of officer and assailant actions and words prior to the assault are quite distinct. For ambushes, a majority of officers were engaged in routine or passive behavior, and no act by assailants other than the attack itself could be identified in nearly 70 percent of the cases" ( $p$ 121). Usually, the officer was not aware of anything occurring that was out of the ordinary until the assailant affected the strike. In general municipal assaults, the contrast could not have been greater than that between robbery-related and ambush attacks.

General municipal assaults, as reported by Meyer, et al., 1981, “...were preceded by much verbal, nonphysical communication, prior to the attack." Thus, they explained, in these kinds of situations the opportunity for personalities, emotions and egos, to affect the course of events was present. General municipal assaults, as reported earlier, seem to grow out of situations in which conflict was already present and aggression was directed against officers. The possibility remains that some of the assaults may have been officer precipitated and accelerated by either abusive or harassing behavior directed toward the suspects. In robbery-related events, they are probably governed as much by the robbery situation itself, as the now desperate and frightened offender may resort to violence against the police as means of avoiding capture and arrest. In conclusion, the general municipal police assaults were more likely to grow out of emotional and conflict-ladened situations which typify many crimes of violence; robbery- related assaults are more likely to involve the robbery situation itself, coupled with the sudden confrontation between suspect and police; ambush attacks develop out of the suspects intentional and conscious desire to either harm or kill the police officer, usually from a position of concealment (Meyer, et al. 1981, pp. 1213).

Comparative Analysis (2010-2012)

In 2010, there were 56 officers feloniously killed. Of the 55 victim officers killed by firearms, 38 (69 percent) were wearing body armor at the times of their deaths. Sixteen (29 percent) fired their weapons. Seven officers (13 percent) attempted to use their own weapons. Twenty (36 percent) did not use or attempt to use their weapons. In thirteen (23 percent) cases, it was not reported whether the officer used or attempted to use their weapon. Seven victim officers had their weapons stolen; seven officers (13 percent) were killed with their own weapons. Of the 69 alleged assailants involved in the felonious killings of officers, 57 ( 83 percent) had prior criminal arrests (LEOKA, 2010). 
In 2011, 72 officers were feloniously killed, 63 with firearms. Ten officers attempted to use their weapons, 17 officers fired their weapons. Records indicate that 43 officers did not use or attempt to use their weapon. Of the 77 involved assailants who killed officers in 2011, 64 (83 percent) had prior criminal arrests (LEOKA, 2011).

The 72 law enforcement officers feloniously killed in 2011, representing a 28 percent increase in officer deaths over $2010(n=56)$ : a 50 percent increase over $2009(n=48)$ and a 76 percent increase over $2008(n=41)$. In 2011, for the first time in 14 years, more officers were killed by gunfire than died accidentally in the line of duty. (Traffic crashes have typically been the leading cause of death).

In 2012, there were 48 officers feloniously killed. Of the 44 victim officers killed by firearms, 24 (55 percent) were wearing body armor at the times of their deaths. Seven officers (16 percent) fired their weapons. Two officers ( 5 percent) attempted to use their own weapons. 35 ( 80 percent) did not use or attempt to use their weapons. In four ( 9 percent) cases, it was not reported whether the officer used or attempted to use their weapon. Three victim officers had their weapons stolen; one officer ( 2 percent) was killed with their own weapon. Of the 51 alleged assailants involved in the felonious killings of officers, 33 (65 percent) had prior criminal arrests (LEOKA, 2012).

A number of questions commonly arise about these fatal shooting events. The U.S. Department of Justice/Federal Bureau of Investigation study conducted in 1992 examined questioning the ability of officers to defend themselves and why officers are not using their weapons during assaults. The data they examined showed that 46 of the 54 victim officers, 85 percent, did not fire their service weapons (DOJ/FBI, 1992).

Generally, for law enforcement officers who were feloniously killed from 2003 to 2012, as shown in Table 7 , the victim officers use of weapons during incidents varied from 47.0 percent, who did not use or attempt to use their own weapon, to $\quad 38.0$ percent of officers who attempted to use their own weapon or actually fired their own weapon.

Certainly there are many scenarios and possible reasons why officers were unable or unwilling to use (or prepared to use) their weapons. Author Dean Scoville (2011) provides some additional insight: "One controversial question that many law enforcement trainers and tactical experts are beginning to raise is whether some of the current generation of officers are really suited to the job."

Table 7: Victim Officer's Use Of Weapon During Felonious Incident (2003-2012)

\begin{tabular}{lcc}
\hline Weapon Disposition & Number Of Officers & Percent \\
\hline Fired own weapon & 123 & 23.0 \\
Attempted to use own weapon & 80 & 15.0 \\
Did not use or attempt to use own weapon & 252 & 47.0 \\
Use of weapon not reported & 80 & 15.0 \\
$\quad$ Total & $\mathbf{5 3 5}$ & $\mathbf{1 0 0 . 0}$ \\
\hline
\end{tabular}

Source: DOJ/FBI LEOKA 2012:12

Scoville also suggests that police officers have different levels of weapon proficiency and tactics and vary as to their willingness to deploy them. Thus, Scoville states, just as some officers display different degrees of proficiency with their weapons and tactics, so, too, do they exhibit varying degrees of enthusiasm in deploying them. Accordingly, "Police agencies thus find themselves alternately trying to encourage some officers to display greater initiative in using necessary force and reining in the more assertive types" (2011). Scoville further explains that the public is generally made aware of the violence used by officers but "...are less likely to hear about are those officers who routinely use too little force because they are either not capable or not so inclined" (2011).

A composite picture of police killed during the 2003-2012, as displayed in Table 8, shows that 95.5 percent were male; the vast majority (94.7 percent) were white; the majority were in the age range of 25-40 years of age; and 57.2 percent had tenure ranging from 1 to 10 years of service and 40.2 percent of all deaths occurred among the oldest tenure category. 
Table 8: Profile Of U.S. Law Enforcement Officers Killed (2003-2012)

\begin{tabular}{|c|c|c|}
\hline GenderVictim Officers' Characteristics & Number & Percent \\
\hline Male & 511 & 95.5 \\
\hline Female & 24 & 4.5 \\
\hline Total & 535 & 100.0 \\
\hline \multicolumn{3}{|l|}{ Race } \\
\hline White & 453 & 84.7 \\
\hline Black & 69 & 12.9 \\
\hline Asian/Pacific Islander & 7 & 1.3 \\
\hline American Indian/Alaskan Native & 6 & 1.1 \\
\hline Total & 535 & 100.0 \\
\hline \multicolumn{3}{|l|}{ Age } \\
\hline Under 25 year of age & 25 & 4.7 \\
\hline $25-30$ years of age & 100 & 18.7 \\
\hline $31-40$ years of age & 215 & 40.2 \\
\hline Over 40 years of age & 192 & 35.8 \\
\hline Unknown & 3 & .6 \\
\hline Total & 535 & 100.0 \\
\hline \multicolumn{3}{|l|}{ Tenure } \\
\hline Less than 1 year of service & 11 & 2.0 \\
\hline 1 to 10 years of service & 306 & 57.2 \\
\hline Over 10 years of service & 215 & 40.2 \\
\hline Not Reported & 3 & .6 \\
\hline Total & 535 & 100.0 \\
\hline
\end{tabular}

Source: Federal Bureau of Investigation, Law Enforcement Officers Killed and Assaulted, Washington, D.C.: U.S. Department of
Justice, 2012: 6,7.

In summation, Scoville argues that the officer who fails to use force when needed is "every bit a threat to the profession and the public as the one hell-bent on getting notches on his gun," rendering themselves and their officers to vulnerable violent assaults.

In developing the composite table of circumstance(s) that officers who were feloniously killed faced at the time of their attacks, the data as shown in Table 9, reveals that 535 law enforcement died during the time period 2003-2012. Conventional understanding of the deadliness of incident type would probably not have placed 115, or 21.5 percent of all deaths, with ambush attacks. More commonly, the uninitiated in the field of officer safety and injury would have placed such circumstances as responding to disturbance calls, or routine traffic stops. However, as shown in the table below, 23.2 percent of the deaths took place in arrest situations, followed by 18.0 percent in traffic pursuit/stop, and 12.0 percent in disturbance calls. Investigating suspicious persons or circumstances resulted in 60 deaths or 11.2 percent of all incidents.

Table 9: Officers Feloniously Killed By Circumstance At Scene (2003-2012)

\begin{tabular}{|c|c|c|}
\hline Circumstance & Number Feloniously Killed & Percent \\
\hline Arrest Situation & 124 & 23.2 \\
\hline Ambush & 115 & 21.5 \\
\hline Traffic Pursuit / Stop & 96 & 18.0 \\
\hline Disturbance Call & 64 & 12.0 \\
\hline Investigating Suspicious Persons/Circumstance & 60 & 11.2 \\
\hline $\begin{array}{l}\text { Tactical Situation (barricaded offender, hostage taking, } \\
\text { high-risk entry, etc.) }\end{array}$ & 43 & 8.0 \\
\hline Handling/Transporting/Custody of Prisoner & 14 & 2.6 \\
\hline Investigative Activity (surveillance, search, interview, etc.) & 13 & 2.4 \\
\hline Handling Person with Mental Illness & 6 & 1.1 \\
\hline Total & 535 & 100.0 \\
\hline
\end{tabular}

Source: LEOKA REPORT, 2012:Table 19 


\section{A Descriptive Profile Of Officers Feloniously Killed In 2012}

In the development of a descriptive profile of the officers who died in 2012 as a result of a felonious attack, 32 of the 48 fallen officers were killed with handguns, 7 with rifles and 3 with shotguns. (In two incidents, the type of weapon was not identified). One was killed with a knife or other cutting instrument, one was killed with personal weapons (hands, fists, feet), and 2 were killed with vehicles. The average age of the officers who were killed was 38 years. Average height was 5'10" and average weight was 207 pounds. The slain officers' average length of law enforcement service was 12 years. (The height, weight and length of service profile have changed little in the past ten years). Most of the officers who died were male (43) and 5 were female. By race, 42 of the victim officers were white, 6 were black. And, 22 officers were killed in the South, 8 in the West, 6 were killed in the Midwest, 6 were killed in the Northeast. Five (5) officers were killed in Puerto Rico and one officer in the U.S. Virgin Islands.

\section{Circumstances Associated With Felonious Attacks In 2012}

Of the 48 officers feloniously killed in 2012, 12 were killed during arrest situations ( 25 percent); ); 8 were killed in vehicle pursuits or stops (16.7 percent); 8 were killed while investigating suspicious persons or circumstances (16.7 percent), 6 were killed in ambush situations (12.5 percent), 5 were killed (10.4 percent) during tactical situations (barricaded offender, high risk entry, hostage taking, etc.); 4 officers were killed responding to disturbance calls ( 8.3 percent); 3 were killed while transporting or maintaining custody of a prisoner ( 6.3 percent). One officer was killed while conducting investigative activity (surveillance, search, interview, etc.) (2.0 percent), and one officer was killed while dealing with a mentally ill subject (2.0 percent).

\section{A Descriptive Profile Of Assailant Characteristics In Felonious Deaths Of Officers In 2012}

\section{Demographic Characteristics}

In 2012, of the 51 offenders who killed law enforcement officers the following personal characteristics were identified. The average age of the alleged offenders was 31 years old; the average height was 5 feet 10 inches tall, and the average weight was 177 pounds. As reported over time, the vast majority of attackers were male $(n=49)$ or (96 percent); and two were women. The majority $(\mathrm{n}=30)$ were white (58.8 percent), 16 were black (31.3percent), and one was an American Indian/Alaskan Native. Race was not reported for three of the offenders. Thirty-three (64.7 percent) of the offenders had prior criminal arrests. Interestingly, as it pertains to alcohol and/or drug use at the time of the attack, 35.2 percent $(n=18)$ of the alleged offenders were under the influence of alcohol or drugs.

In Table 10, the general profile of police assailants involved in the felonious deaths of police shows that very few demographic changes have taken place during the combined period of 2003 to 2012. As summarized nearly 98 percent of assailants were male, 51 percent were white, and 54 percent were within the age range of 18 to 30. Also, black assailants are disproportionately represented (43.5 percent) as a percent of the total population. 
Table 10: Profile Of Assailants Identified In Felonious Killings Of Law Enforcement Officers (2003-2012)

\begin{tabular}{lcc}
\hline \multicolumn{1}{c}{ Assailant Characteristics } & Number & Percent \\
\hline Gender: & 582 & 97.8 \\
\hline Male & 13 & 2.2 \\
Female & $\mathbf{5 9 5}$ & $\mathbf{1 0 0 . 0}$ \\
Total & & 51.1 \\
\hline Race: & 304 & 43.5 \\
\hline White & 259 & 2.9 \\
Black & 17 & 2.5 \\
Other & 15 & $\mathbf{1 0 0 . 0}$ \\
Race Not Reported & $\mathbf{5 9 5}$ & 5.2 \\
Age: & & 54.1 \\
\hline Under 18 Years of Age & 31 & 20.3 \\
18-30 Years of Age & 322 & 10.8 \\
31-40 Years of Age & 121 & 7.4 \\
41-50 Years of Age & 64 & 2.2 \\
51+Years of Age & 44 & $\mathbf{1 0 0 . 0}$ \\
Age Not Reported & 13 & $\mathbf{5 9 5}$ \\
Total & & \\
\hline
\end{tabular}

Source: LEOKA 2012:42, 44

\section{Characteristics Of Officers Assaulted}

The magnitude of the assaults of law enforcement officers and the number of officers killed for the 1960 to 2012 period is presented in Table 11. The number of assaults was less than 10,000 per year in 1960, and rose to 81,000 in 1992 - an increase of 745 percent. This amazing increase, even if it is partially due to better record keeping, is dramatic. Similarly, the number of police officers murdered has increased nearly fourfold since 1960 when 28 officers were killed, but rose to well over 100 officers killed during the high tide of the middle seventies - a 343 percent increase.

The evidence of assaults shows a distinctive pattern. Table 11 reveals the absolute number of law officers assaulted since 1960. At the same time that the assault numbers increased, so did the number of police officers murdered increase. The number of antipolice assaults may merely mirror the increased number of officers employed in the United States. If this is true, then the rate of anti-police violence may not have increased at all. Further, two distinct trends are evident over time. First, there was a substantial increase in total assaults during the 1960s reaching its height at the start of the 1970s. Then as the Viet Nam war was drawing to a close the assaults on police suddenly began to drop. Since the middle 1970s the number of police assaults has remained quite stable through 2012 - persistently in the 50,000 range.

When dealing with assaults reported to the FBI it is imperative that the reliability and veracity of the actual reporting is taken into consideration. It is of interest to note that not all governmental jurisdictions accurately and completely report all the crimes committed in their respective areas of authority. Indeed, some critics have argued that the reporting of crime and the crime trend may be influenced politically and therefore is reflected in "crime fighting by erasure" (Meyer, 2002).

Further, as shown, the rate of assaults per 100 officers has varied from a low of 6.3 assaults per 100 officers in 1960 to a high of 18.7 in 1970 and 1971, respectively. Since 1994, the rate has continued to be consistently below 14.0 assaults per 100 officers, reaching a thirty year low of 10.9 in 1997 . During the period 1967 to 1995 the rate of officers assaulted has generally ranged between 13.5 and 17.5. Since 2000, the assault rate has continued a downward trend line, reaching its lowest rate of 10.2 in 2012 - similar to the lowest rates that occurred in the middle 1960s.

Additionally, the rate per 100 officers assaulted that resulted in injury follow the general pattern of assaults describes earlier. In 1965 there were 6,836 reported assaults with injury for a rate of 3.6 - the lowest reported rate in 
the forty-eight year history of the FBI reporting this data. Since then, perhaps coincidently with the involvement of the US in the Viet Nam War, the rate has ranged from 4.6 in 1966 to the middle 5 to the middle 6 rate ending in 1975. Since 1975, except for a few outlier years, the pattern associated with the rate of injuries per 100 officers has shown a steady decline reaching its lowest rates reported in the 2001 to 2012 period.

Table 11: Assaults And Murders Of Law Enforcement In The United States (1960-2012)

\begin{tabular}{|c|c|c|c|c|c|}
\hline Year & Total Assaults & $\begin{array}{c}\text { Rate Per 100 } \\
\text { Officers }\end{array}$ & $\begin{array}{c}\text { Assaults With } \\
\text { Injury }\end{array}$ & $\begin{array}{c}\text { Rate Per 100 } \\
\text { Officers }\end{array}$ & $\begin{array}{l}\text { Number Of Police } \\
\text { Officers Murdered }\end{array}$ \\
\hline 1960 & 9,621 & 6.3 & $\mathrm{NR}^{\mathrm{a}}$ & NR & 28 \\
\hline 1961 & 13,190 & 8.3 & NR & NR & 37 \\
\hline 1962 & 17,330 & 10.2 & NR & NR & 48 \\
\hline 1963 & 16,793 & 11.0 & NR & NR & 55 \\
\hline 1964 & 18,001 & 9.9 & 7,738 & 4.3 & 57 \\
\hline 1965 & 20,523 & 10.8 & 6,836 & 3.6 & 53 \\
\hline 1966 & 23,851 & 12.2 & 9,113 & 4.6 & 57 \\
\hline 1967 & 26,755 & 13.5 & 10,770 & 5.4 & 76 \\
\hline 1968 & 33,604 & 15.8 & 14,072 & 6.6 & 64 \\
\hline 1969 & 35,202 & 16.9 & 11,949 & 5.7 & 86 \\
\hline 1970 & 43,171 & 18.7 & 15,165 & 6.6 & 100 \\
\hline 1971 & 49,768 & 18.7 & 17,631 & 6.6 & 126 \\
\hline 1972 & 37,523 & 15.1 & 12,230 & 5.8 & 112 \\
\hline 1973 & 32,535 & 15.0 & 12,880 & 5.9 & 127 \\
\hline 1974 & 29,511 & 15.1 & 11,468 & 5.9 & 132 \\
\hline 1975 & 44,867 & 15.4 & 18,974 & 6.5 & 129 \\
\hline 1976 & 49,079 & 16.8 & 18,737 & 6.4 & 111 \\
\hline 1977 & 49,156 & 15.3 & 17,663 & 5.5 & 93 \\
\hline 1978 & 56,130 & 16.1 & 21,075 & 6.2 & 93 \\
\hline 1979 & 59,031 & 17.3 & 21,764 & 6.4 & 106 \\
\hline 1980 & 57,847 & 16.7 & 21,516 & 6.2 & 104 \\
\hline 1981 & 57,116 & 17.2 & 20,272 & 6.1 & 91 \\
\hline 1982 & 55,755 & 17.5 & 17,116 & 5.4 & 92 \\
\hline 1983 & 62,324 & 16.5 & 20,807 & 5.5 & 80 \\
\hline 1984 & 60,153 & 16.2 & 20,205 & 5.4 & 72 \\
\hline 1985 & 61,724 & 15.8 & 20,817 & 5.3 & 78 \\
\hline 1986 & 64,259 & 16.9 & 21,639 & 5.7 & 66 \\
\hline 1987 & 63,842 & 16.8 & 21,273 & 5.6 & 73 \\
\hline 1988 & 58,752 & 15.9 & 21,015 & 5.7 & 78 \\
\hline 1989 & 62,172 & 16.4 & 21,893 & 5.8 & 66 \\
\hline 1990 & 71,794 & 17.4 & 26,031 & 6.3 & 65 \\
\hline 1991 & 62,852 & 15.5 & 23,650 & 5.8 & 71 \\
\hline 1992 & 81,252 & 17.6 & 29,673 & 6.4 & 63 \\
\hline 1993 & 66,975 & 14.7 & 24,031 & 5.3 & 70 \\
\hline 1994 & 64,912 & 13.5 & 23,194 & 4.8 & 78 \\
\hline 1995 & 57,686 & 13.5 & 16.181 & 3.8 & 74 \\
\hline 1996 & 46,695 & 12.5 & 14,985 & 4.0 & 56 \\
\hline 1997 & 49,151 & 10.9 & 13,105 & 2.9 & 65 \\
\hline 1998 & 59,545 & 13.4 & 18,198 & 4.4 & 61 \\
\hline 1999 & 55,026 & 11.7 & 16,285 & 3.5 & 42 \\
\hline 2000 & 56,054 & 12.7 & 15,915 & 3.6 & 51 \\
\hline 2001 & 56,666 & 12.2 & 16,202 & 3.5 & 70 \\
\hline 2002 & 58,066 & 12.0 & 16,494 & 3.4 & 56 \\
\hline 2003 & 57,841 & 12.0 & 16,339 & 3.4 & 52 \\
\hline 2004 & 59,373 & 11.9 & 16,563 & 3.3 & 57 \\
\hline 2005 & 57,546 & 11.9 & 15,763 & 3.2 & 55 \\
\hline 2006 & 58,634 & 11.8 & 15,704 & 3.2 & 48 \\
\hline 2007 & 59,201 & 11.4 & 15,479 & 3.0 & 58 \\
\hline 2008 & 58,792 & 11.3 & 15,366 & 3.0 & 41 \\
\hline 2009 & 57,268 & 10.3 & 14,905 & 2.7 & 48 \\
\hline 2010 & 53,469 & 10.0 & 13,962 & 2.6 & 56 \\
\hline 2011 & 54,774 & 10.2 & 14,578 & 2.7 & 72 \\
\hline 2012 & 52,901 & 10.2 & 14,678 & 2.8 & 48 \\
\hline
\end{tabular}

${ }^{a}$ NR: Not reported in Uniform Crime Reports until 1964. Source: Federal Bureau of Investigation. Uniform Crime Reports, Washington, D.C.: U.S. Department of Justice, 1960-2012. 


\section{Officers Assaulted By Region (2003-2012)}

Table 12 shows, for the time span of 2003-2012, there were 569,799 law enforcement officers assaulted in the United States and the rate of officer assaults averaged 10.2 per 100 officers. As a percentage of total assaults for this period, the lowest percentage of assaults took place in the Northeast, and the highest percentage occurred in the South census region (47.7 percent). Again, these geographical variations are similar to those reported previously for felonious deaths of officers.

Table 12: Officers Assaulted By Region (2003-2012)

\begin{tabular}{|c|c|c|}
\hline Region & Number & Percent \\
\hline Northeast & 76,569 & 13.4 \\
\hline Midwest & 77,301 & 13.6 \\
\hline South & 271,723 & 47.7 \\
\hline West & 144,206 & 25.3 \\
\hline Total & 569,799 & 100.0 \\
\hline
\end{tabular}

Source: Federal Bureau of Investigation, Law Enforcement Officers Killed and Assaulted, Washington, D.C.: U.S. Department of Justice, 2001; 34, 2002; 34, 2003; 52, 2004; 63, 2005; 63, 2006; 63; 2007; 65, 2008; 65, 2009; 65 and 2010; 65, $2012 ; 65$.

\section{Analysis Of Police Officer Assaults For 2012}

Of the 52,901 officers assaulted in 2012, the data is consistent with the longitudinal data reported in Table 10 above. As shown in Table 13 below, the lowest percentage of total assaults reported took place in the Northeast, and the highest was in the South with 13.4 percent and 43.3 percent, respectively.

Table 13: Officers Assaulted By Region (2012)

\begin{tabular}{lccc}
\hline \multicolumn{1}{c}{ Region } & Number Of Assaults & Percent & Assault Rate Per 100 Officers \\
\hline Northeast & 7,089 & 13.4 & 8.2 \\
Midwest & 7,515 & 14.2 & 9.9 \\
South & 22,885 & 43.3 & 10.2 \\
West & 15,412 & 29.1 & 11.6 \\
$\quad$ Total & $\mathbf{5 2 , 9 0 1}$ & $\mathbf{1 0 0 . 0}$ & \\
\hline
\end{tabular}

Source: LEOKA; 2012; 65

Although the actual tables are not reported here, a brief description of the assault against police incidents that occurred in 2012 has the general characteristics as reported below.

\section{Weapons Used In Assault On Police}

In 2012, agencies reported that 52,901 officers were assaulted, resulting in 14,678 officers (27.7 percent) sustaining injuries. 80.2 percent of officers attacked by assailants using personal weapons such as hands, fists or feet, resulted in 29.7 percent of those officers sustaining injuries. Some 13.2 percent of those officers assaulted with knives or other cutting instruments were injured. Other dangerous weapons were used in 23.9 percent of the officers assaulted. Firearms were involved in the attacks 4.3 percent of the time, resulting in 9.8 percent of officer injuries. Last, in 1.7 percent of the cases, knives or other cutting devices were used and officers received injuries in 13.2 percent of those cases.

\section{Time Of Day For Assault}

The time period of 12:01 a.m. to 2:00 a.m. saw the most injuries (15.2 percent) inflicted on officers. For the past 14 years, most assaults have occurred during this time period. The smallest percentage of officers (2.5 percent) was assaulted during the period between 6:01 a.m. and 8:00 a.m. 


\section{Investigation Or Enforcement Activities}

Officers responding to disturbance calls (family disputes, bar fights, etc.) experienced the highest assault rate of 32.5 percent, followed by officers attempting to make arrests, where 15.2 percent of officers were assaulted. Approximately 13.6 percent of officers who were injured were handling, transporting or maintaining custody of prisoners.

\section{Patrol Unit Type}

Regarding assignments at the time of the assault, 64 percent of the officers assaulted were assigned to 1officer patrol vehicles, while 16 percent were assigned to two-officer patrols.

\section{Behavioral Characteristics Of Assaulted Officers}

In the FBI Report, "Violent Encounters: A Study of Felonious Assaults on our Nation's Law Enforcement Officers" (2006), the following characteristics or "behavioral descriptors" were used to describe the officers who were assaulted in the study;

Officers assaulted were considered friendly; hard-working; service-oriented; prepared to react; willing to use force when justified; failed to follow established procedures, especially in regard to arrests, handling prisoners, traffic stops, calling and waiting for backup (when available); reads people or situations and inappropriately drops guard; and is a survivor (p. 19).

It is not surprising that the FBI would report this behavioral profile of the assaulted officers in 2006, since it mirrored what they reported earlier in 1992 about officers who were feloniously killed. They wrote that the victim officers, for 1975-1985, had these general traits; "Friendly to everyone; well-liked by community and department; tends to use less force than other officers felt they would use in similar circumstances; hard working; tends to perceive self as more public relations than law enforcement - - service oriented; uses force only as last resort - peers claim they would use force at an earlier point in similar circumstances; doesn't follow all the rules, especially in regard to arrest, confrontation with prisoners, traffic stops; does not wait for back-up (when available); feels he/she can "read" others/situations and will drop guard as a result; tends to look for "good" in others (and, is) "laidback" and "easy-going" (FBI, 1992: 52).

Given that these generalized behavioral profiles may be more anecdotal than empirical, Meyer et al. state, "that studies like those reported here, have found one of two things: first, that no relationship exists at all between officer psychological characteristics and the chance of assault and, second, a few studies have found a very weak relationship on one or two of the dozens of measures that were employed. However, such weak relationships can be dismissed as just chance occurrences given the large number of variables used." In short, that there is no systematic evidence that shows a strong relationship between the probability of assault and officer personality type. Meyer concludes, "...assaults seems to result mostly from the officers' role in society as the enforcer (Meyer, et al., 2001; p. 131).

A number of assaulted officers stated that they should have maintained a more professional demeanor while still displaying a friendly manner. Ironically, a potential assailant may sometimes view a friendly demeanor as a weakness.

The victim officers in the study (like most officers in the field) possessed a preconceived image of the kind of person they considered likely to assault them. These descriptions, however, varied from officer to officer. In correlating the physical characteristics of the offenders participating in this study to the characteristics of the officers in the 1992 study, the data suggest that there is no singular profile of an individual who would assault, attempt to kill, or actually kill a police officer. Of the 52 victim officers interviewed in the FBI study, only 18 (34.6 percent) stated that they were aware that they were about to be attacked. These data support the assumption that officers' preconceived ideas of their notion of who might assault them were of little value in securing their personal safety (FBI, 2006). 
It is clear that the image, the attitude and the demeanor of the officer all play a role in an encounter. Their level of alertness, attentiveness, and voice are important. Exhibiting professionalism, alertness and confidence can sometimes help deter an assault.

The FBI study (2006:162) found that,

... the officer's demeanor must convey that, if necessary, he or she is prepared to be a formidable opponent. The officer's mannerisms, traits, and behaviors must reveal a readiness or preparedness. Such behaviors are observed and interpreted by subjects on the street. It is not only what one does, it is how one does it. Although officers cannot control certain elements of a deadly confrontation, they can greatly influence other elements.

Furthermore, officers are often in a particularly unenviable position in society. They are called upon when threats of violence are anticipated or actual incidents of violence have taken place. They are expected to contain the aggression and to defuse the situation when everyone else has failed to accomplish these peacekeeping measures. But, when the action has ended and the scene is safe, judgments are made regarding the decisions and actions the officers took. It is seemingly unfair when the actions of officers who made those decisions within seconds because their lives and lives of others were threatened are judged in safety and at leisure by individuals with little exposure to such violence. However, supervision, oversight, and analysis of violent encounters involving law enforcement are important and necessary. One must remember that such encounters can result in individuals' freedom being taken away and in some cases, even their lives.

Examination of the various components of the deadly mix should be made by everyone who investigates, reviews, or reports on these violent encounters. There is no easy equation into which the circumstances of each violent encounter can be placed to answer why it occurred and what amount of responsibility each player had. It is only by a careful, impartial, and unbiased examination of each of these events that the facts of the case will surface and an objective and honest assessment will be made.

Unfortunately, sometimes the officer simply lacks basic facts and information about the call they may be responding to. Worse yet, they may actually disregard (or misinterpret the information they have received) altogether. Combine this with an instance where the officer chooses to ignore their training along with disregard of department policies (i.e. not calling for or nor waiting for back-up), and bad things are bound to happen.

Although there is no consensus on the ultimate solutions to the problem of antipolice violence, the physical and psychological characteristics of individual officers seem to have little impact on their chances of being assaulted or murdered. Instead, what makes the most difference for individual officers is the dangerousness of their particular assignments, the geographical areas where they work, and the specific situations that they face in their duties. (Meyer et al., 1979; Brunk et al., 1999a; Brunk et al., 1999b; Meyer et al., 2001)

\section{General Characteristics Of Assailants}

The profile of known offenders who have feloniously killed officers has also changed little over the years. From 2003 to 2012, the average age of an offender was 30 years. The assailants averaged 5'10" in height and 179 pounds. In 2012, the average age of an offender was 31, with an average height of 5'10" and 177 pounds.

In the various studies conducted by the FBI, they interviewed a variety of assailants who killed or severely assaulted a law enforcement officer. Often the assailant said the attack on the officer "wasn't personal." The attack was often based on the "appearance and demeanor" of the officer, as well as the basic desire of the assailant to "get away" and avoid detention or arrest. A number of assailants stated that the attack was prompted by the officer "not being professional or respectful." Often times, the assailant would attack the officer if he/she showed a lack of attention, fear, or disrespected the assailant in some way.

What can be done to deter assaults against police officers? In retrospect, it is clear that one key area to focus on is the officer themselves. While easier said than done, it is important for an officer to be (and appear to be) confident and competent. To do that, they must have adequate training and proper equipment. Their training must 
include detailed application in the use of force. The officer must be prepared (when necessary) to fight - and win when they become engaged in a physical encounter. The FBI warns: "A most dangerous time for officers is when they begin to disregard or shortcut their safety training" (FBI, Violent Encounters, 2006). This all begins with a professional, confident and competent appearance. An officer must pay attention and remain focused before, during and after contact with a citizen. Virtually all officers know this, yet it gets ignored because of other distractions. Clearly, complacency may be related to officers' injury and/or death.

\section{Societal Considerations}

Given the lack of a particular offender profile, and given that physical characteristics per se are not reliable indicators of likelihood to assault or kill an officer, the FBI Violent Encounters report that the most salient fact regarding individuals who might assault or kill - "...it can be anyone" (FBI, 2006).

In their book, The Sources of Violence in America and Their Consequences for Law Enforcement, authors Meyer, Brunk and Wilson (2001) state that the role of the police in American society is a difficult one at best. The police are assigned the task of imposing force, and they are expected to deal with unauthorized and illegal conflict and violence. Most fundamentally, they are the state's violence officers, and distracting and often time consuming duties in the area of community service does not make their lives appreciably safer. Also, they sometimes are caught in politically volatile problems that are not of their making, and they have no way to solve them.

In his study of Los Angeles police officers, Steve Herbert (1996) concluded that most officers are basically moral individuals who interpret their societal function terms of a special type of police morality. This is because of the three important, and largely unique, facets of their role. First, there is the contradiction between their fundamental aim of preventing crime and their inability to achieve this objective. Second, law enforcement officers often find that it is necessary to run roughshod over the ambiguity that is ubiquitous in many police situations. Finally, officers usually have to act against the interests of some civilians during any confrontation situation (Meyer, et al., 2001)

Additionally, it is noted by Meyer, et al. (2001:114), "The badge and the gun constitute two powerful symbols of authority. They may be used in a totally legitimate manner, in a manner that violates the legal rights of civilians, in a manner that is legally correct, or used so offensively that officers become the immediate cause of the assaults directed against them. The violence that is directed against police officers is to a great extent caused by their role in society - especially if they are negatively viewed and feared among certain segments of society such as recent immigrants and black and Hispanic youth, and others who are most likely to have encountered the behavior of rogue cops. As such, it appears that antipolice violence may be a special case of American violence that is not easily explainable using conventional criminological theory."

Dean Scoville, (2011) states that,

Finding the root of the carnage is problematic and the answers are elusive. Felonious killings of officers spring from a variety of sources; from a suspect's chemically impaired judgment, paranoid ideation, or personal agenda; to and officer's inability to adequately respond to a threat; to inefficiencies in police administration; to a fateful intersection of time and circumstance. In a trio of studies dedicated to law enforcement safety, the FBI dubbed this confluence of variables the "deadly mix.

Another factor in the rising police body count is that criminals have increased their level of tactical sophistication and weaponry. Law enforcement is constantly reacting to society's demands for change based on past events. In the aftermath of any high-profile incident, officers' actions are dissected and placed under a microscope for all to analyze. Even those with little or no expertise in the matter have their say in the media and other forums. Department administrators devote so much time and effort responding to these concerns that they lose sight of new threats that loom around the corner. As yesterday's policy changes are implemented, officers are faced with every new challenge that today's suspects bring." 


\section{Geographical Variations}

Violence against the police in America has a long and complicated history. Without question, the issue of violence against the police is a complex societal dilemma. Even after many years of collecting and attempting to interpret the data about law enforcement officer deaths, the FBI finds answers elusive...particularly when attempting to identify causes of the disproportionate number of crimes, assaults and murders of police officers in the South.

Overall, the FBI study (2006:48) was unable to explain adequately the preponderance of law enforcement officer deaths in the South and they stated, "Much speculation continues to exist regarding this phenomenon. However, the difficulties in explaining the cultural and structural aspects of crime and punishments in the southern United States have also been, and continue to be, a focus of much research by academic criminologists. An understanding of the factors that may contribute to the likelihood of an officer being killed clearly goes beyond simple regional variations. The type of assignment, the circumstances at the scene of the encounter, the weapons used in these incidents, and the environment in which these events occur also play a role in the ultimate death of the law enforcement officer."

Most studies of antipolice violence lack statistical control groups, which are useful for making comparisons and ensuring that one's conclusions are correct. Even census data is of little use in verifying most research conclusions because census tracts rarely correspond with police reporting jurisdictions. As a result, it is impossible to be certain if a particular characteristic increases the probability that a person will assault a police officer. Perhaps that characteristic just happens to be more common in areas where assaults are common, but is not related to the probability of an individual assaulting an officer.

Meyer, et al. attempted to deal with regional variability and stated that "While the United States is a relatively violent society, ... the propensity to use violence and particularly to use violence against law enforcement officers," shows much variation across the 50 states. They further state "one aspect of this variability is that which is a legally acceptable level of force in one jurisdiction may not be an acceptable act in another jurisdiction for either a police officer or a civilian." Indeed, they argue that the South represents a region of "exceptionalism" on many things, including the use of violence to settle disputes. Of course, this leads to the culture of honor and where one's honor is of penultimate concern there is little agreement in civil society in what is "right and wrong, good and evil, virtuous and immoral." Thus in the South, they argue "the sort of ethical rules that formed nineteenth and twentieth centuries Northern society are virtually unknown," and "therefore, the Southern threshold for justifying the legitimate use of violence is much lower than in most parts of the country" (Meyer, et al., 2001: 157-169).

This view is also presented by Cohen and Vandello: "The South shares with other cultures of honor one central theme; a common conception of the insult as something that drastically reduces one's social standing and a belief that violence can be used to restore that standing once it has been jeopardized". (Cohen and Vandello 1998: 569).

In drawing their conclusion on the regional variability of violence, Meyer, et al. 2001: 112 state "...it should not be surprising to learn that more law enforcement officers are assaulted in the South and many more law enforcement officers are killed in Southern states than in other parts of the country." In general, violence is seen as a more legitimate way to redeem one's honor and the actions of police officers are seen as less legitimate during times of physical disputes.

"The South shares with other cultures of honor one central theme; a common conception of the insult as something that drastically reduces one's social standing and a belief that violence can be used to restore that standing once it has been jeopardized". (Cohen and Vandello 1998: 569). In general, violence is seen as a more legitimate way to solve particular types of problems by Southerners, using it provides a way to redeem one's honor, and the actions of police officers often are seen as less legitimate during times of physical disputes (Brunk et al. 1999, Clark 1998, Cohen and Vandello 1998, Wolfgang and Ferracutti 1967a and 1967b; Meyer, et al., 2001). 


\section{Training \& Equipment}

A key to officer safety is to improve and increase training to counter the increase in violence against police officers. Training standards must be set high. For example, new training is being developed by a variety of sources to address "counter-ambush tactics." More agencies are now training in "close-quarters combat," improved defensive tactics, ground fighting, disarming techniques, pressure point control tactics, back-up weapons, such as guns and knives, and improved firearms training.

Many police agencies recognize the need for the development and use of "dynamic" training and focusing on increasing and improving an officers' "situational awareness." There is importance and benefit to officers learning and practicing "pre-planning" and "visualization" skills. This training would include discussions and experiences with what the FBI refers to as "awareness, image and mindset." When possible, officers need to mentally prepare themselves before they get to the scene of an incident that requires their intervention. Another important piece of this training involves learning controlled breathing. The idea is to arrive on a call in top mental and physical condition, which permits the officer to focus effectively and be fully prepared to take whatever action might be necessary. The purpose of much of the training is to hone the officers' street survival skills.

Effective participation in realistic and dynamic training is critical (Meyer, et al., 2001). It is also imperative that all officers develop a satisfactory level of ability in applying the training. Some departments have been slow in adopting new training techniques or they may fail in this area because of insufficient funding or manpower availability. In some agencies, officers routinely miss or intentionally skip training for a variety of reasons. Clearly, this is not sound policy and should not be permitted; for those officers, who miss a training session for whatever reason, should be required to make it up as soon as possible.

More tactical protocols are being developed and implemented as well. For instance, additional education and training that deals with "active shooters," which unfortunately, seem to be more commonplace in today's society. Similarly, specialized training is growing in the area of "high risk entries." These might take place during the raid of a drug house, serving a search or arrest warrant, or during a barricaded subject situation. This is an area that has seen a sharp increase in officer injuries and fatalities in recent years.

The studies also show that officers sometimes simply need to learn and practice patience. They must learn to wait for backup. And, they must learn to "arrive prepared" perhaps by having their guns already drawn and ready. They need to think about the nature of the call... and respond accordingly. A number of officers have been killed after arriving at the scene of a call where their radio dispatcher told them there were weapons present. Yet, they approached rather casually, without their guns in the ready position. Clearly, providing officers as much information as possible about a call before they arrive and training officers to develop and maintain a heightened sense of situational awareness is critical. Another important training topic includes developing an officer's real understanding of the use of force. The updating, continuous refinement and routine review of use-of-force policies by agencies is helping officers to better understand not only when and specifically how force may be used, but how to prepare themselves for its implementation - and how to accurately document it afterward. Sometimes officers are reluctant to raise their level of force because they fear they will be wrong or be open to discipline and criticism. This hesitation may have cost lives of officers. It is critical every officer understands the appropriate use of force and how and when to apply it if and when needed... without hesitation.

Since the difference between assaulting an officer and murdering an officer is largely a matter of chance, once one has taken into account the weapon that is used by an assailant, the decline in the number of police murders probably has resulted from two sources. The first is the increased level of professionalism of law enforcement officers, particularly in the South, where the greatest decline in police deaths has occurred. "The second is far better protective equipment, including body armor, which has prevented numerous deaths" (Meyer, et al., 2001).

Nationally, many departments are implementing mandatory, ongoing physical fitness training for officers. Obtaining and maintaining a high level of physical fitness and proficiency in defensive tactics and firearms training is paramount to surviving a potentially deadly encounter, as mentioned by officers who have experienced and survived dangerous situations. Routinely practicing these skills is also important. Meaningful skill development 
(and maintenance) in various defensive tactics training is key to officer survival. Additional skill development in oral communications, observation skills, and dealing with mentally or emotionally impaired/disturbed individuals should be a part of any police agencies' training program. Training that addresses the mentally ill is becoming more common throughout the country. This may prove to be mutually beneficial for both the public and the officers responding. Once an officer gets a call to respond - or observes a situation first hand that requires their attention they should attempt to gather all the information possible before making contact. They need to approach cautiously, stay focused and be prepared...every single time. They may need to call, then wait for, backup to arrive. They may need to take and maintain cover (which differs from concealment) when possible. They must develop and exercise a physical, mental and situational awareness and be prepared to react immediately and appropriately.

Unfortunately, many officers frequently have insufficient information and/or facts about the people or situation to which they are being sent. It is critical that radio dispatchers try to gain and share any and all information about the situation and environment to which they are sending an officer. The reality of the street, however, is that sometimes there is little information available, or, the officer has no choice but to intervene quickly into a situation. Regrettably, it is very easy for officers to become complacent. Indeed, most of the stops they make and calls they respond to turn out to be "uneventful." However, officers cannot afford to take anything for granted. They must maintain a relatively high level of alertness and awareness immediately before, during and until after a contact is made. Officers must strive to maintain a winning mindset (sometimes referred to as "hyper-vigilance") when making stops or approaching people. Most studies that have interviewed officers who have survived an encounter in which they were assaulted and seriously injured indicate that the officers initially believed that particular stop was "routine" or for a "minor offense" and the person did not appear to be any sort of threat. ALL officers should learn from and heed this sage advice.

In 2009, a study conducted by the Police Executive Research Forum determined that 41 percent of police departments did not require their officers to actually wear body armor at least some of the time. Of the 55 officers killed by firearms in 2010, only 38 (69 percent) were wearing body armor. This is such an important finding, that in March 2011, U.S. Attorney General Eric Holder met with law enforcement officials from around the country to discuss this issue. Police agencies around the country were directed by the Justice Department to start requiring their officers to wear body armor or risk losing millions of dollars in federal aid that support such efforts.

In 2011, of the 63 officers killed by firearms, 46 (73 percent) were wearing body armor. This is up since 1997, when only 40 percent of officers killed by firearms were wearing body armor. Technological advancements in body armor make it much lighter, tougher, more flexible and cooler, thus more likely to be worn. In 2012, 24 of the 48 officers feloniously killed (50 percent) were wearing body armor. Accordingly, more departments are now mandating that body armor be worn.

In 2012, the Police Executive Research Forum conducted a follow-up survey of police departments throughout the country and found that 92 percent now have policies requiring their officers to wear body armor either at all times or most of the time, with a few qualified exceptions. This is a positive move that will save lives of officers. Additionally, there is recognized benefit of officers wearing body armor who are involved in shootings, physical assaults with other weapons and motor vehicle crashes as well. Obviously, the body armor helps protect their torso from trauma, thereby helping to save lives. Certainly, increased use of body armor will help, but will generally not aid those officers who are shot in the head, neck or other exposed portions of their body. It is apparent that criminals are "gearing up" by obtaining and using larger more powerful weapons as well as shooting officers in areas of the body (i.e., the head) that are not protected by body armor. In fact, in many of the more brazen cases, the criminals are themselves wearing body armor and using multiple weapons. Many are thinking more "tactically" and "strategically" by even having thought out escape routes or exit strategies.

Dean Scoville (2011) says it best in that "technological innovation is only one part of mitigating the deadly hazards faced by American law enforcement officers. Selecting the best candidates and providing them with an environment-both physically and politically-in which they can perform their jobs more safely may be even more critical to officer survival. "The FBI (1992) states, "The cases reviewed and presented have dramatically illustrated the need to avoid a lax mental attitude when performing law enforcement duties. Rarely was a single element the cause of these law enforcement fatalities. The holistic approach of positive departmental safety procedures, related 
and timely training and first-line safety supervision can and will save lives." Dale Willits (2006) makes the point that departments with protective gear regulations, more stringent education requirements for police recruits, and higher proportions of black officers, experience less violence against their police officers. Furthermore, cities with African American mayors, when controlling other factors, tend to have less violence against their police officers.

\section{DISCUSSION, RECOMMENDATIONS AND CONCLUSION}

Despite the best efforts to improve officer safety, the number of officers feloniously killed and assaulted remains somewhat constant. It has proven difficult to significantly reduce these numbers. What more can be done? The FBI believes a meaningful part of the answer to this question can be found in understanding the "deadly mix" as developed and explained in the "Killed in the Line of Duty" study (1992). The deadly mix consists of three components: the officer, the offender, and the circumstance that brought them together, and may provide a basis for why law enforcement assaults and deaths still continue at unacceptable levels despite advances in technology, equipment and new police strategies.

According to the FBI, along with the three components of a violent encounter (the officer, the assailant and the circumstance) another key element that officer must understand is the role of perception. A number of case studies they conducted indicate there are a number of differences in the perception of the circumstance and event by the officer and the assailant. By improving and increasing realistic training to officers related to understanding and identifying these various misperceptions and perceptual discrepancies could save officers' lives.

"Although there is no consensus on the ultimate solutions to the problem of antipolice violence, the physical and psychological characteristics of individual officers seem to have little impact on their chances of being assaulted or murdered. Instead, what makes the most difference for individual officers is the dangerousness of their particular assignments, the geographical areas where they work, and the specific situations that they face in their duties" (Meyer, et al., 2001, p.173). Factors such as, assignment type, patrol units size, body armor policies and type, communications between dispatch and officer that provides real-time data relevant to the dangerousness, are largely outside the officers ability to control, they are important to consider if occupational injuries to police are to be reduced".

Not only has the increased level of American violence had negative effects on those who suffer from its use, but also violence may have almost as serious a set of consequences on those who employ it and those who witness it. Repeated exposure to violence dulls the moral sensitivities of users, victims, and witnesses alike. The result is empathy fatigue where people have an increasingly difficult time feeling sympathy and compassion for others. If violence breeds violence, as many people believe, then once violence has been used, people are more likely to use it again. Over time, this tends to reduce a person's ability to choose a humane approach to social interaction (Meyer, et al., 2001 p. 33). Furthermore, society must start to consider and further research what the consequences of exposure to violence may have on police officers over time.

From a methodological perspective, the lack of statistical controls means that many of the inferences about antipolice violence are tenuous. In turn, this is a major reason why there are so many competing theories about police assaults and murders, and why there is no consensus about their sources. Since the available evidence is not sufficient to justify an all-encompassing theory of police assaults, it must be used in conjunction with careful logical analysis to come to reasonable conclusions about the most likely causes of such violent acts. (Meyer 2001:115)

Even census data is of little use in verifying most research conclusions because census tracts rarely correspond with police reporting jurisdictions. As a result, it is impossible to be absolutely sure if a particular characteristic increases the probability that a person will assault a police officer. Perhaps that characteristic just happens to be more common in areas where assaults are common, but is not related to the probability of an individual assaulting an officer.

"While voluminous amounts of data has been collected on police assaults and injuries these data have not been collected in ways that allow testing of the predictions of various theories. One the one hand, when such aggregate-level data as the types of and numbers of antipolice assaults by state are collected, the individual-level 
attributes of the assault situations cannot be identified. One the other hand, it is so expensive and time-consuming to gather evidence on individual-level characteristics that they have been collected for very limited geographical areas, and it is unlikely that all the findings from such studies can be generalized."

Furthermore, there often is little evidence on the potentially important characteristics of assailants, and so their contributions cannot easily be integrated into a general model of antipolice violence. Even when this sort of data is gathered, a statistical control group that allows for comparisons of the same characteristics among people who did not assault officers is rarely available. This lack of statistical control means that any inferences about the individual-level causes of such violence remain tenuous, at best. Problems also abound in terms of having compatible reporting bases for aggregate-level police data, and rarely do census tracts match precincts or police reporting districts.

While highly sophisticated models characterize much of the theoretical literature, and the anecdotal writings are full of potentially testable hypotheses, the types of data that have been collected so far on antipolice violence have not allowed researchers to easily test the predictions of most models. As the FBI Study so succinctly put it in their assessment of the attempt to fully and accurately portray the perpetrators of antipolice violence:

Theories of human aggression involve either the extreme position suggesting that behavior is the result of purely internal mechanisms or controlled by external stimuli - or some combination of these factors.... Clearly, the answer to the "why" of human aggression in general has not been reached. Nor is there a satisfactory explanation to why individuals kill law enforcement officers. (FBI Study 1992:15)

It remains possible for reasonable people to hold many divergent views about causes of antipolice violence since there is not enough evidence to discredit most perspectives. This means that public policy in this area is in disarray because the multitude of theories about such violence suggests quite varied prescriptions. Much of the literature remains anecdotal and ideological, rather than quantitative and scientific. It may be a long time before definitive answers can be discovered to the major questions in this field. Indeed, there probably are no quick fixes to be found here, but if the future research on antipolice violence remains disjointed and specific to half-a-dozen disciplines, rather than systematic, comprehensive and cross-disciplinary, few advances will be made toward answering the most important questions in this area.

Because of all these caveats, society must be very careful in summarizing what is known about the sources and ultimate causes of police assaults and murders. Some of the most meaningful research questions require data collected at the individual-level for the officer, the offender, and the situational context of the assault. The problem is that precious little is known about what occurs in the mind of the violent offender, or, for that matter, in the mind of the assaulted or killed officer. While the FBI Study tried to provide answers to some of these problems, their sample of 50 murderers of police officers may be such an idiosyncratic one that few valid generalizations can be made from it. Such an assessment will remain unclear unless much more statistically representative data can be collected of the sort used in the FBI Study to verify its conclusions (Meyer, et al., 2001: 171).

Researchers must find more effective means and methods to gather facts and data in order to thoroughly and accurately interpret the events related to killings and assaults of law enforcement officers and must commit the time and resources to ensure proper collection of the necessary data with appropriate scientific and statistical methodology and vigor. Collecting and interpreting the necessary data to ensure scientific criteria is being met is extraordinarily difficult, time consuming and extremely expensive. Lack of control groups and true random sampling are only a few of the shortcomings of current and previous research. Conducting dependable and effective research on this topic is fraught with pitfalls, uncertainties and perhaps some impossibilities. With quantitative data must also be sound qualitative analysis. The use of statistical control variables in analyzing relationships is key to success, but heretofore has not been applied to this type of research to any real extent. Diligence must be exercised in order to separate folklore from established truth.

The authors conclusion remains similar to what Meyer et al., (2001) stated, "While the nature and root causes of violence have been extensively studied, it is far from being fully understood. Until more effective methods of data collection can be developed, much of the public debate about antipolice violence will remain rhetorical and ideological, rather than scientific and fact based. Much more comprehensive research is necessary" (p. vi). 


\section{AUTHOR INFORMATION}

Randy R. Edwards is a retired Chief of the Law Enforcement Bureau of the Iowa Department of Natural Resources. He has nearly 35 years of law enforcement, supervisory and training experience. He holds a B.A. degree in Criminal Justice and a Master's degree in Public Administration (with emphasis in Executive Development) from Drake University. He is also a graduate of the Certified Public Managers Program at Drake University and the National CPM Consortium. He is the Past President of the National Association of State Boating Law Administrators (NASBLA) and the Past Vice President of the Association of Natural Resource Enforcement Trainers (ANRET). He has co-authored a case study (with C. Kenneth Meyer) entitled "A Hiring Dilemma: Recruitment from In-House Versus from Outside" in Managing People as Assets. He is an adjunct instructor at Simpson College in Indianola, Iowa. E-mail: redwards800@ gmail.com

C. Kenneth Meyer is a Thomas F. Sheehan Distinguished Professor of Public Administration, Drake University. He previously held teaching positions at Winona State University, State University of New York, University of South Dakota, and the University of Oklahoma, Norman, Oklahoma. He has nearly 300 published case studies that appear in numerous venues. His latest books are entitled: Managing People as Assets; Human Relations in Action; Managing America's Organizations; Managing Public Service Organization; Conducting the People's Business; and Organizational Change. His newest book, with Jeffrey Geerts is entitled Nonprofit Management and Leadership Case Studies (2014). E-mail: kenneth.meyer@drake.edu (corresponding author).

Stephen E. Clapham is a Pro fessor of management in the Drake college of Business and Public Administration. $\mathrm{He}$ earned his Ph.D. from Indiana University. He has published research in the areas of trust, ethics, strategic planning, organizational voice, and impression management. E-mail: steve.clapham@drake.edu.

\section{REFERENCES}

Brunk, G.G., Meyer, C. K., \& Wilson-Gentry, L.A. (1999a). A Theoretical Perspective on Violence Against Government Authority. Public Administration and Management, http://www.spaef.com/article/335/ATheoretical-Perspective-On-Violence-Against-Governmental-Authority

Brunk, G.G., \& Meyer, C.K. (1999b). Sports, Politics, and other Gold Rush Games: Why Bad Guys are Increasingly the Winners. Public Integrity: 2, 29-43.

Caulfield, P. (2011, December 13). Number of On-Duty Police Officer Deaths Jumps in 2011: Report. New York Daily News, Retrieved from http://www.nydailynews.com/news/national/number-on-duty-police-officerdeaths-jumps-2011-report-article-1.990700

Center for Disease Control and Prevention: Workplace Safety and Health Topics, Retrieved from http://www.cdc.gov/niosh/topics/violence/

Clarke, J.W. (1998). Without Fear or Shame: Lynching, Capital Punishment and the Subculture of Violence in the American South. British Journal of Political Science, 28: 269-290.

Cohen, D., and J. Vandello. (1998). "Meanings of Violence," Journal of Legal Studies 27: 569.

Greenhouse, S. (2010, August 20). The Most Dangerous Jobs in America. The New York Times: Economix, Retrieved from www.economix.blogs.nytimes.com/2010/08/20

Herbert, S. (1996). Morality in Law Enforcement: Chasing the "Bad Guys" with the Los Angeles Police Department. Law and Society Review, 30:799-818.

Meyer, C.K., Magedanz, T.C., Kieselhorst, D.C., \& Chapman, S.G. (1979). Violence and the Police: The Special Case of the Police Assailant. Journal of Police Science and Administration, 7: 161-171.

Meyer, C.K., Magedanz, T.C., Dahlin, D.C., \& Chapman, S.G. (1981). A comparative Assessment of Assault Incidents: Robbery Related, Ambush, and General Police Assaults. Journal of Police Science and Administration, 9: 1-18.

Meyer, C.K., Magedanz, T.C., Dahlin, D.C., \& Chapman, S.G. (1982). An Analysis of Factors Related to RobberyAssociated Assaults on Police Officers, Part I. Journal of Police Science and Administration, 10: 1-17.

Meyer, C.K., Magedanz, T.C., Feimer, S.H., Chapman, S.G., \& Pammer, W.J. (1986). Ambush Related Assaults Against Police Officers: Violence at the Street Level. Springfield, IL: Charles C. Thomas, Publisher, Ltd.

Meyer, C.K., Brunk, G. G., \& Wilson, L. A. (2001). The Sources of Violence in America and Their Consequences for Law Enforcement. Springfield, IL: Charles C. Thomas, Publisher, Ltd. 
Occupational Safety and Health Administration: Workers' Rights, Retrieved from https://www.osha.gov/Publications/osha3021.pdf

Romano, S. J., Levi-Minzi, M.E., Rugala, E. A., \& Van Hasselt, V. B. (2011, January). Workplace Violence Prevention Readiness and Response. FBI Law Enforcement Bulletin, Retrieved from http://leb.fbi.gov/2011/january/workplace-violence-prevention-readiness-and-response

Scoville, D., (2011a, July). Line of Duty Deaths: The War on Cops. Police Magazine, Retrieved from http://www.policemag.com/magazine/2011/07.aspx

Scoville, D. (2011b, August). Line of Duty Deaths: Managing Risk. Police Magazine, Retrieved from http://www.policemag.com/channel/patrol/articles/2011/08/risk-management.aspx

United States Census Bureau: http://www.census.gov

United States Department of Homeland Security, Federal Emergency Management Agency, IS-906: Workplace Security Awareness, Retrieved from http://training.fema.gov/is/courseoverview.aspx?code=IS-906

United States Department of Justice, Federal Bureau of Investigation, Criminal Justice Information Services Division, Washington D.C.: Various Years 1960 to 2012. Retrieved from http://www.fbi.gov/about-us/cjis

1) Killed in the Line of Duty: A Study of Selected Felonious Killings of Law Enforcement Officers. (1992).

2) In the Line of Fire: Violence Against Law Enforcement. (1997).

3) Violent Encounters: A Study of Felonious Assaults on Our Nation's Law Enforcement Officers. (2006).

4) Law Enforcement Officers Killed and Assaulted (LEOKA). (1989:12, 1999:18, and 2009:19).

5) Uniform Crime Reports. (1960-2012).

United States Department of Labor, Bureau of Labor Statistics: Beyond the Numbers, August 13, Retrieved from http://www.bls.gov/opub/btn/volume-2/death-on-the-job-fatal-work-injuries-in-2011.htm

United States Department of Labor, Bureau of Labor Statistics: Census of Fatal Occupational Injuries, Retrieved from http://www.bls.gov/iif/osh_nwrl.htm\#cfoi

United States Department of Labor, Bureau of Labor Statistics: National Census of Fatal Occupational Injuries in 2012, Retrieved from www.bls.gov/news.release/archives/cfoi_08222013.pdf

United States Department of Labor: Bureau of Labor Statistics. (2012). Statistics on Fatal Work injuries. Retrieved from http://www.bls.gov/iif/oshwc/cfoi/cfch0006.pdf

United States Department of Labor, Bureau of Labor Statistics: News Release, Retrieved from http://www.bls.gov/news.release/archives/cfoi_08222013.pdf

United States Department of Labor, Occupational Safety \& Health Administration, OSHA Law \& Regulations, Retrieved from www.OSHA.gov/law-regs.html

United States Department of Labor, Occupational Safety and Health Administration, Safety and Health Topics: Workplace Violence, Retrieved from www.osha.gov/SLTC/workplaceviolence/

United States Department of Labor, Occupational Safety \& Health Administration: Safety and Health Topics, Retrieved from https://www.osha.gov/SLTC/workplaceviolence/

Willits, D.W. (2006). "Disorganization, Conflict, and Organizational Characteristics: What Are the Structural Correlates of Violence Against Police Officers?" University of New Mexico.

Wolfgang, M.E., \& Ferracutti, F. (1967a). Violence and Robbery: A Case Study. Acta Criminologica. 5: 11-1-6.

Wolfgang, M.E., \& Ferracutti, F. (1967b). "The Subculture of Violence: Towards an Integrated Theory in Criminology. London: Tavistock. 